\title{
Successful use of vancomycin hydrochloride in the treatment of lactulose resistant chronic hepatic encephalopathy
}

\author{
K Tarao, T Ikeda, K Hayashi, A Sakurai, T Okada, T Ito, H Karube, T Nomoto, T Mizuno, \\ K Shindo
}

\begin{abstract}
Vancomycin hydrochloride $(2 \mathrm{~g}$ daily) was administered to 12 patients with cirrhosis and lactulose resistant portal systemic encephalopathy in a double blind crossover trial. All 12 patients showed a remarkable clinical improvement after vancomycin treatment. The mean (SE) electroencephalographic (EEG) frequency changed from $6 \cdot 3(0.2)$ to $8 \cdot 5$ $(0.2)$ cps $(p<0.001)$ and the mean arterial ammonia concentration from $152(4) \mu \mathrm{g} / \mathrm{ml}$ to $97(8) \mu \mathrm{g} / \mathrm{ml}(\mathbf{p}<0 \cdot 001)$. Their clinical condition deteriorated when treatment was switched to lactulose, returning to the previous slower EEG frequency and high arterial ammonia concentrations. Vancomycin seems to be effective in chronic portal systemic encephalopathy in patients who are not helped by lactulose alone.
\end{abstract}

In recent years, chronic recurrent portal systemic encephalopathy in patients with cirrhosis has generally been treated with restriction of dietary protein and oral lactulose. There are, however, occasional patients with portal systemic encephalopathy who do not respond to oral lactulose treatment and develop hepatic encephalopathy despite this drug. Although a specific amino acid solution, Fischer's solution, has also been advocated in severe hepatic encephalopathy in patients with cirrhosis, ${ }^{12}$ it is difficult, in practice, to administer over a long period of time.

We have recently shown that vancomycin hydrochloride, a non-absorbable antibiotic which is effective against anaerobic Gram negative rods but ineffective against aerobic ones, ${ }^{3-6}$ is useful in controlling portal systemic encephalopathy in patients with cirrhosis. ${ }^{46}$ It has also been shown that changes in blood ammonia concentrations correspond very well with changes in the number of anaerobic Gram negative rods in faeces. ${ }^{+7}$

We therefore gave vancomycin hydrochloride to cirrhotic patients with portal systemic encephalopathy that was resistant to oral lactulose. We examined changes in their faecal bacterial flora and report the effectiveness of this antibiotic in these subjects.

\section{Methods}

PATIENTS

Fourteen of 29 consecutive patients with cirrhosis and portal systemic encephalopathy admitted to Kanagawa Cancer Center Hospital and Kawasaki Kyodo Hospital between 7 April 1986 and 10 March 1988, whose portal systemic encephalopathy was resistant to continuous lactulose administration, were admitted to the study. There were 13 men and one woman. The proportion of lactulose resistant patients was high because many had been transferred to these two centres from outlying hospitals. The diagnosis of liver cirrhosis was made by laparoscopy and examination of liver biopsy specimens. Rupture of oesophageal varices occurred in one man soon after vancomycin hydrochloride administration, and he was excluded from the study. One woman was unable to continue taking vancomycin because of severe nausea and she was also excluded. Twelve patients finished the study.

None of the 12 patients had abused alcohol for more than two years and the liver lesion was biochemically and histologically inactive in all but one, who showed only mild activity.

All patients had given informed consent and the research was carried out according to the declaration of Helsinki.

\section{STUDY DESIGN}

Before the trial the patients were admitted to hospital for two weeks (the control period) for assessment of their clinical condition. During this period lactulose was given to all patients and the amount was adjusted individually to induce two to four bowel movements a day. Protein intake was restricted to about $50 \mathrm{~g}$ daily and there were no changes in diet during the trial period. At the end of the two week assessment period, the mental status of the patients was evaluated and graded according to the criteria suggested by Parsons-Smith et al, ${ }^{8}$ modified by Conn et al. ${ }^{9}$ The mean encephalographic (EEG) frequency was estimated, the fasting arterial ammonia concentration was measured by a modified method of Okuda and Fujii, ${ }^{10}$ and a bacteriological study of stools was done.

The trial then started. During the first eight weeks all patients were given $1000 \mathrm{mg}$ of vancomycin hydrochloride (VCM, Shionogi Pharmacological Co, Tokyo, Japan) orally twice daily - at 6 am and at $6 \mathrm{pm}$. The vancomycin was diluted in distilled water to a volume of $30 \mathrm{ml}$. At this dose vancomycin has a mildly laxative property and produces one to three semi-formed stools per day. Once the vancomycin administration had been established, the patients were discharged and followed for eight weeks as outpatients. During this period, clinical and EEG assessments were made twice weekly. After 


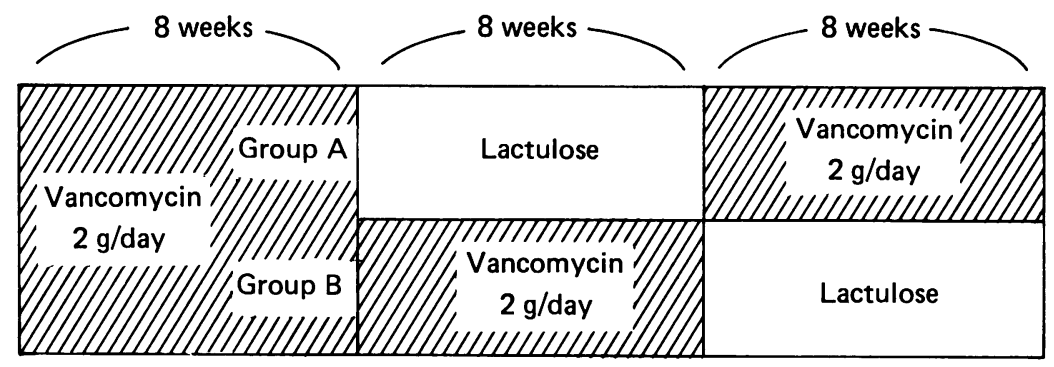

Figure 1: Design of the vancomycin hydrochloride trials. During the first eight weeks all 12 patients received vancomycin hydrochloride in a single blind trial. The patients were then randomised to a double blind crossover trial of vancomycin hydrochloride $\mathrm{v}$ lactulose.

eight weeks the patients were readmitted to hospital for a further two weeks and the same assessments were performed as during the control period.

The double blind randomised crossover study of vancomycin $v$ lactulose was performed as follows: six patients (group A) selected at random were changed to lactulose alone immediately after the initial eight weeks on vancomycin, while the remaining six (group B) remained on vancomycin for another eight weeks. After this period, the medication was reversed and the study was continued for a further eight weeks (Fig 1). The amount of lactulose given was again adjusted individually as described previously and the procedure for giving vancomycin was the same as it had been at the beginning of the study.

All the analyses of EEG and bacterial flora were conducted on a double blind (ie coded) basis.

During the subsequent study, these 12 patients remained clinically stable with no gastrointestinal bleeding, electrolyte abnormalities, constipation, or infection and they all completed the study.

The patients' characteristics in each group at the beginning of the study were as follows: group A comprised six men and group B five men and one woman. There was no significant difference in the mean (SE) age between group A $(58 \cdot 3(4 \cdot 2)$ years) and group $B(61 \cdot 0(4 \cdot 3)$ years). The type of cirrhosis in group A was alcoholic in four patients, posthepatitic in one, and cryptogenic in one. In group $\mathrm{B}$ it was alcoholic in three, posthepatitic in one, and cryptogenic in two patients.

With regard to liver histology, the ratio of

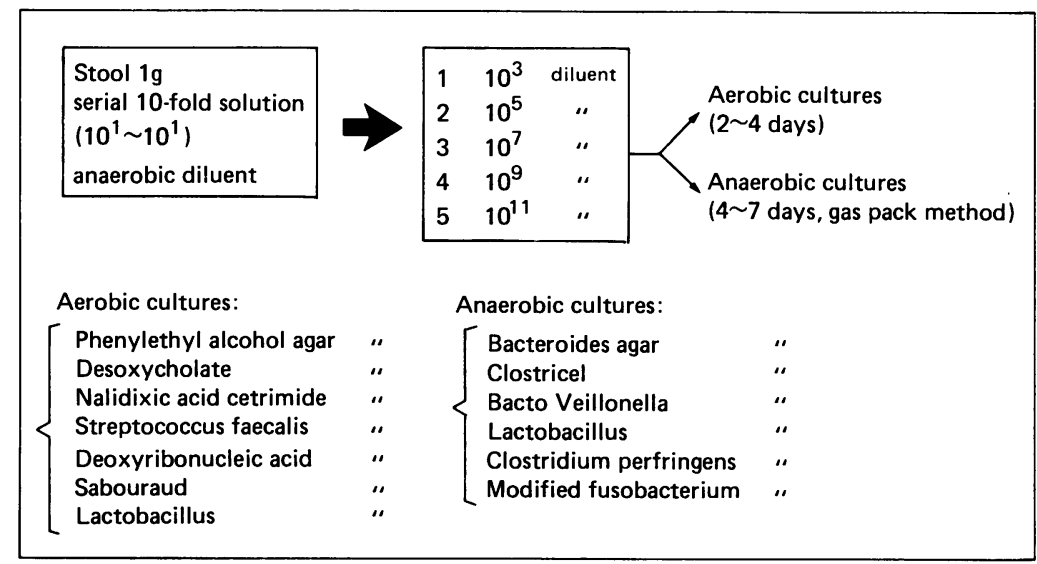

Figure 2: Bacteriological investigation of faecal flora. micronodular: macronodular: mixed nodular cirrhosis was 1:3:2 in group A and 1:4:1 in group B. The average duration of encephalopathy was $2.0(0.6)$ years in group A and $1.7(0.4)$ years in group $B$.

The biochemical data for the two groups at the beginning of the study were as follows: serum albumin concentration (normal range, $4 \cdot 0-5 \cdot 0$ $\mathrm{g} / \mathrm{l})$ was $3 \cdot 4(0 \cdot 2)$ in group A and $3 \cdot 1(0 \cdot 2)$ in group $B$, serum aspartate transaminase activity (normal range $<40 \mathrm{IU} / \mathrm{l}$ ) was $66(8)$ in group A and 45 (8) in group B, serum alkaline phosphatase activity (normal range $<10 \mathrm{KAU} / \mathrm{l}$ ) was $9.8(1.0)$ in group A and 10.3 (1.7) in group B, total bilirubin concentration (normal range 5-17 $\mu \mathrm{mol} / \mathrm{l}$ ) was $23(2)$ in group $A$ and 22 (6) in group $B$, and indocyanine green retention $(15$, normal range $0-10 \%)$ was $45 \cdot 7(5 \cdot 5) \%$ in group $\mathrm{A}$ and $41.9(3.6) \%$ in group B. There were no significant differences between group A and group B in any of these parameters.

\section{BACTERIOLOGICAL STUDY}

Bacteriological studies of faecal flora were carried out as shown in Figure 2. A $1 \mathrm{~g}$ specimen of each fresh stool was subjected to serial 10 -fold dilution immediately after defecation. The anaerobic diluent consisted of $4 \mathrm{~g} \mathrm{KH} \mathrm{KO}_{4}$, $6 \mathrm{~g} \mathrm{Na}_{2} \mathrm{HPO}_{4}, 1 \mathrm{~g} \mathrm{~L}$-cystein, $1 \mathrm{~g}$ agar, and 1000 $\mathrm{ml}$ of distilled water. The dilution was carried out in the glove box anaerobic chamber. A standard loopful of the diluent was inoculated onto the specially designed culture media shown in Figure 2. The aerobic plates were incubated for two to four days. The anaerobic plates were incubated for four to seven days by the gas pack method. Isolated strains of both aerobes and anaerobes were identified according to Bergey's classification."

\section{STATISTICAL ANALYSIS}

Statistical comparisons of the data were made using the paired Student's $t$ test.

\section{Results}

As shown in Table I the grade of hepatic encephalopathy improved in all 12 patients when vancomycin was given. The improvement was

TABLE I Changes in the grade of encephalopathy in the 12 patients with lactulose resistant chronic hepatic encephalopathy given vancomycin hydrochloride (according to the criteria suggested by Parsons-Smith et al and modified by Conn et al)

\begin{tabular}{lll}
\hline & \multicolumn{2}{l}{ Grade of encephalopathy } \\
\cline { 2 - 3 } Patient & Before vancomycin & After vancomycin \\
\hline 1 & 2 & 0 \\
2 & 2 & 0 \\
3 & 3 & 1 \\
4 & 2 & 0 \\
5 & 2 & 0 \\
6 & 2 & 1 \\
7 & 2 & 0 \\
8 & 2 & 0 \\
9 & 1 & 0 \\
10 & 2 & 0 \\
11 & 2 & $0 \cdot 2(0 \cdot 2)$ \\
12 & 3 & - \\
Mean (SE) & $2 \cdot 0(0 \cdot 3)$ & $\mathbf{p}<0 \cdot 001$ \\
& &
\end{tabular}


TABLE II Changes in the mean EEG frequency after vancomycin hydrochloride administration in the 12 patients with lactulose resistant chronic hepatic encephalopathy

\begin{tabular}{lll}
\hline & \multicolumn{2}{l}{ Mean EEG frequency (cps) } \\
\cline { 2 - 3 } Patient & Before vancomycin & After vancomycin \\
\hline 1 & $5 \cdot 4$ & $7 \cdot 7$ \\
2 & $6 \cdot 8$ & $8 \cdot 9$ \\
3 & $6 \cdot 3$ & $8 \cdot 5$ \\
4 & $7 \cdot 0$ & $8 \cdot 7$ \\
5 & $5 \cdot 6$ & $8 \cdot 9$ \\
6 & $5 \cdot 9$ & $8 \cdot 9$ \\
7 & $6 \cdot 1$ & $8 \cdot 3$ \\
8 & $6 \cdot 4$ & $9 \cdot 2$ \\
9 & $6 \cdot 5$ & $7 \cdot 1$ \\
10 & $6 \cdot 2$ & $8 \cdot 7$ \\
11 & $5 \cdot 9$ & $8 \cdot 3$ \\
12 & $7 \cdot 1$ & $8 \cdot 4$ \\
Mean (SE) & $6 \cdot 3(0 \cdot 2)$ & $8 \cdot 5(0 \cdot 2)$ \\
& &
\end{tabular}

TABLE III Changes in arterial ammonia concentration in 12 patients with lactulose resistant chronic hepatic encephalopathy during the vancomycin hydrochloride (VCM) trial period

\begin{tabular}{|c|c|c|}
\hline Group & Time period & $\begin{array}{l}\text { Arterial ammonia } \\
(\mu g / m l) \\
(\text { Mean }(S E))\end{array}$ \\
\hline $\begin{array}{l}\text { Group A } \\
\text { (Lactulose } \rightarrow \text { VCM group) } \\
(\mathbf{n = 6 )}\end{array}$ & $\begin{array}{l}\text { Control } \\
\text { VCM } \\
\text { Lactulose } \\
\text { VCM } \\
\end{array}$ & $\begin{array}{r}154(6) \\
93(8)] \mathrm{p}<0.001 \\
150(4) \\
102(14)] \mathrm{p}<0.02\end{array}$ \\
\hline $\begin{array}{l}\text { Group B } \\
(\text { VCM } \rightarrow \text { lactulose group) } \\
(n=6)\end{array}$ & $\begin{array}{l}\text { Control } \\
\text { VCM } \\
\text { VCM } \\
\text { Lactulose }\end{array}$ & $\begin{array}{l}150(6) \\
101(15)] p<0.02 \\
105(11) \\
148(4)] p<0.01\end{array}$ \\
\hline
\end{tabular}

usually evident after two to three days of treatment. In 10 patients the encephalopathy resolved completely and in the remaining two only grade I encephalopathy persisted. The grade of encephalopathy after vancomycin $(0 \cdot 2$ $(0 \cdot 2))$ was significantly $(\mathrm{p}<0.001)$ less than that beforehand $(2 \cdot 0(0 \cdot 3))$. The EEG frequency after vancomycin $(8.5(0.2) \mathrm{cps})$ was significantly $(\mathrm{p}<0.001)$ larger than that beforehand $(6 \cdot 3(0 \cdot 2)$ cps) (Table II).

In the crossover double blind study, the tendency was the same. In group A, the mental status deteriorated when patients were crossed to lactulose, and improved again when they crossed back to vancomycin. In group B, the improvement in mental status persisted for about two months, and thereafter it deteriorated in five of six patients when they were crossed to lactulose.

ARTERIAL AMMONIA CONCENTRATION Table III shows the changes in the arterial

TABLE IV Changes in faecal bacterial flora in 12 patients with lactulose resistant chronic hepatic encephalopathy during the vancomycin hydrochloride (VCM) trial

\begin{tabular}{|c|c|c|c|}
\hline \multirow[b]{2}{*}{ Group } & \multirow[b]{2}{*}{$\begin{array}{l}\text { Time } \\
\text { period }\end{array}$} & \multicolumn{2}{|c|}{ Bacterial counts/g of stool } \\
\hline & & $\begin{array}{l}\text { Anaerobic } \\
\text { Gram negative rods }\end{array}$ & $\begin{array}{l}\text { Aerobic } \\
\text { Gram negative rods }\end{array}$ \\
\hline $\begin{array}{l}\text { Group A } \\
\text { (Lactulose } \rightarrow \text { VCM group) } \\
(n=6)\end{array}$ & $\begin{array}{l}\text { Control } \\
\text { VCM } \\
\text { Lactulose } \\
\text { VCM }\end{array}$ & 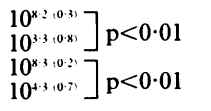 & 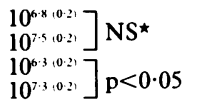 \\
\hline $\begin{array}{l}\text { Group B } \\
\left(\begin{array}{l}\text { VCM } \rightarrow \text { lactulose group }) \\
(n=6)\end{array}\right.\end{array}$ & $\begin{array}{l}\text { Control } \\
\text { VCM } \\
\text { VCM } \\
\text { Lactulose }\end{array}$ & 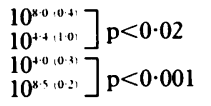 & 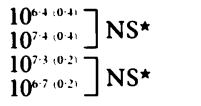 \\
\hline
\end{tabular}

^NS=not significant.
TABLE V Bacteroides sp isolated from the stool of cirrhotic patients with lactulose resistant encephalopathy during control period (before administration of VCM)

\begin{tabular}{|c|c|c|}
\hline Subspecies & No of strains & \\
\hline $\begin{array}{l}\text { Bacteroides fragilis } \\
\text { Bacteroides vulgatus } \\
\text { Bacteroides distasonis }\end{array}$ & $\left.\begin{array}{rr}72 & (31 \cdot 9) \\
11 & (4 \cdot 9) \\
53 & (23 \cdot 5)\end{array}\right\}$ & $136(60 \cdot 2)$ \\
\hline $\begin{array}{l}\text { Bacteroides ovatus } \\
\text { Bacteroides uniformis } \\
\text { Bacteroides thetaiotaomicron } \\
\text { Bacteroides eggerthil }\end{array}$ & $\begin{array}{lr}12 & (5 \cdot 3) \\
45 & (19 \cdot 9) \\
23 & (10 \cdot 2) \\
10 & (4 \cdot 4)\end{array}$ & \\
\hline Total & $226(100 \cdot 0)$ & \\
\hline
\end{tabular}

ammonia concentration in the 12 patients throughout the vancomycin trial. In the control period the mean (SE) ammonia concentration was $152(4) \mu \mathrm{g} / \mathrm{ml}$ and it fell significantly $(\mathrm{p}<0.001)$ to $97(8) \mu \mathrm{g} / \mathrm{ml}$ after vancomycin therapy. The change to lactulose resulted in a return to the previous high values.

\section{FAECAL BACTERIAL FLORA}

Table IV shows the changes that occurred in faecal bacterial flora during the study.

Generally, the count of total anaerobic Gram negative rods ran as high as $10^{7}-10^{9}$ organisms per $\mathrm{g}$ stool before vancomycin (ie when lactulose was given), and by contrast the count became as low as $10^{2}-10^{7}$ after vancomycin. There were significant differences between the control period and the period of vancomycin administration with respect to the log bacterial counts in anaerobic Gram negative rods $(\mathrm{p}<0.01, \mathrm{p}<0.02$, respectively)

The anaerobic Gram negative rods most commonly found in faecal specimens before vancomycin administration were bacteroides, and Bacteroides sp found in that period are shown in Table $\mathrm{V}$.

On the other hand, the counts of aerobic Gram negative rods were $10^{5}-10^{7}$ per $\mathrm{g}$ of stool before vancomycin treatment, and these remained nearly the same or slightly increased afterwards.

\section{Discussion}

The management of chronic recurrent portal systemic encephalopathy is difficult and unsatisfactory. It consisted of restriction of dietary protein and antibiotic suppression of the intestinal bacteria, usually by neomycin until 1967 when lactulose was introduced. This synthetic dissaccharide (1,4-galactoside fructose), which is neither absorbed nor hydrolysed in the upper intestinal tract of man, passes unchanged into the lower bowel where it is metabolised by bacteria with the production of lactic, acetic, and formic acids and carbon dioxide. ${ }^{12}$ It was initially suggested that acidification favoured growth of lactobacilli and other acidophilic fermentative bacteria and suppression of acidophobic proteolytic bacteria ${ }^{13}$ resulting in a decrease in ammonia production in the colon.

It has recently been suggested, however, that a major effect of lactulose is to augment the incorporation of nitrogen (especially ammonia) into faecal bacteria for synthesis of bacterial protein, although nitrogen in the soluble frac- 
tion also increases, and that the increased faecal nitrogen excretion, mostly in the bacterial fraction of stool, would reduce urea synthesis..$^{1+-16}$ The cathartic properties of lactulose and acidification of colonic contents are thought to be of secondary importance in this theory. More recently, it has also been shown that at least half of the total ammonia production in the gut is the result of non-bacterially mediated glutamine degradation in the intestinal wall, ${ }^{17}$ and that lactulose inhibited degradation of glutamine to ammonia in vitro ${ }^{18} 19$ and in vivo. ${ }^{2021}$

Lactulose has been reported to be effective in the treatment of portal systemic encephalopathy by a number of investigators, ${ }^{132223}$ and in recent years a combination of dietary protein restriction and oral lactulose administration has become the most popular treatment for chronic recurrent portal systemic encephalopathy in Japan. There are, however, many patients with cirrhosis and hepatic encephalopathy in whom this combination does not bring about full recovery. A specific amino acid solution like Fischer's solution has been advocated in severe hepatic encephalopathy in these patients. ${ }^{12}$ It is, however, difficult to control chronic recurrent portal systemic encephalopathy for a long period with such a method because of the time and expense needed.

We recently showed that vancomycin, a nonabsorbable antibiotic that suppresses anaerobic Gram negative rods but not aerobic ones, ${ }^{3}$ is very effective in chronic recurrent portal systemic encephalopathy. ${ }^{4-}$

We therefore administered vancomycin to patients with intractable chronic recurrent portal systemic encephalopathy which developed in spite of the oral lactulose treatment. This study shows that vancomycin is surprisingly effective in these patients. It improved their clinical symptoms, EEG abnormalities, and blood ammonia values.

In recent years, it has been shown in vitro that an appreciable proportion of the non-sporing anaerobes, especially bacteroides, produce urease ${ }^{24}$ and that Gram negative anaerobic rods (chiefly bacteroides) are more active than aerobic enterobacteria in the production of ammonia from nutrient medium containing peptides and amino acids. ${ }^{12}$ Indeed the Bacteroides sp isolated in this study belonged to the most active species in ammonia production. Moreover, in 1982 Morgan et $a l^{25}$ showed clinically that in the treatment of hepatic encephalopathy in a series of 11 mildly or moderately affected and seven severely affected patients with histologically confirmed cirrhosis, metronidazole, which is active against bacteroides and other anaerobes, was as effective as neomycin and that metronidazole could also reduce the production of endogenous ammonia by its effect on the anaerobic intestinal flora.

More recently we have shown that bacteroides may be the main producers of ammonia in hepatic encephalopathy in cirrhotic pattients, and that suppression of these bacteria by vancomycin brings about recovery from hepatic encephalopathy in many patients. ${ }^{+7}$

One of the reasons for the effect of vancomycin in lactulose resistant intractable portal systemic encephalopathy could be its ability to decrease
Gram negative faecal anaerobes, especially bacteroides. This study showed a dramatic decrease in the anaerobic Gram negative rods after vancomycin treatment. In contrast, their counts were much higher in patients on lactulose. On the other hand, aerobic Gram negative rod counts remained in the same range during both treatments.

At this point one must consider the mode of action of lactulose and neomycin. Lactulose and neomycin were originally thought to exert their influence on hepatic encephalopathy by interfering with the bacterial flora but Leeuwen et $\mathrm{al}^{1819}$ recently showed a potential additional effect; interference with glutamine dependent nonbacterial ammonia production. It is possible that vancomycin also has a strong inhibitory effect on the non-bacterially mediated degradation of glutamine to ammonia but no data are available on this point at present.

Although further study is required to elucidate the precise mechanism by which vancomycin is effective in lactulose resistant portal systemic encephalopathy, we conclude that this antibiotic is useful in the control of chronic portal systemic encephalopathy in which lactulose alone is ineffective.

We thank emeritus Professor Kunio Okuda of Chiba University for his indispensable assistance in the preparation of the manuscript.

1 Fischer JE, Funovics JM, Aguirre A, et al. The role of plasma amino acids in hepatic encephalopathy. Surgery 1975; 78 276-90

2 Fischer JE, Rosen HM, Ebeid AM, James JH, Keane JM Soeters PB. The effects of normalization of plasma amino acids on hepatic encephalopathy in man. Surgery 1976; 80: 77-91.

3 Funada H, Niwa K, Fujita S, Hattori K. Utility of protected environments and prophylactic antibiotics in bone marrow transplantation. Saishinigaku 1979; 34: 1274-82.

4 Tarao K, Ikeda T, Hayashi K, Sakurai A, Ito T. Clinical significance of anaerobic gram negative bacteria in hepatic encephalopathy [Abstract]. Fpn Med 1985; 74: 204.

5 Tarao K, Ikeda T, Hayashi K, Sakurai A. Clinical significance of anaerobic gram negative bacteria in hepatic encephalopathy and therapeutic effects of vancomycin hydrochloride pathy and therapeutic effects of vancomycin hydrochloride
on hepatic encephalopathy. Jpn Gastroenterol 1985; 82: on hepatic

6 Tarao K, Sakurai A, Okada T, Hayashi K, Ikeda T, Ito T Significance of faecal bacteroides in hepatic encephalopathy with hyperammonemia [Abstract]. Acta Hepatol fpn 1985 26 (suppl): 85

7 Tarao K, Ikeda T, Hayashi K, Sakurai A, Karube H, Ito T Clinical significance of bacteroides in hepatic encephalopathy [Abstract]. Hepatology 1985; 5: 947.

8 Parsons-Smith BC, Summerskill WHJ, Dawson AM Sherlock S. The electroencephalogram in liver disease Lancet 1957; ii: 867-71.

9 Conn HO, Leavy CM, Vlahcevic ZR, et al. Comparison of lactulose and neomycin in the treatment of chronic portallactulose and neomycin in the treatment of chronic portal-

10 Okuda H, Fujii S. Quantitative estimation of blood ammonia by the direct photometric method. Saishinigaku 1966; 21 $622-6$

11 Buchanan RE, Gibbons NE. Bergey's manual of determinative bacteriology. 8th ed. Baltimore: Williams \& Wilkins, 1974.

12 Vince AJ, Burridge SM. Ammonia production by intestina bacteria: the effects of lactose, lactulose, and glucose. $\mathcal{F ~ M e d}$ Microbiol 1980; 13: 177-91.

13 Bircher J, Muller J, Guggenheim P, Haemmerli UP. Treatment of chronic portalsystemic encephalopathy with lactulose. Lancet 1966; i: 890-92.

14 Weber FL Jr, Banwell JG, Fresard KM, Cummings JH Nitrogen in fecal bacteria, fiber and soluble fractions of cirrhotic patients: Effects of lactulose and lactulose plus neomycin. $\mathcal{F}$ Lab Clin Med 1987; 110: 259-63.

15 Douwes AC, Van Der Burg GJ, Bouman AA, Jakobs C Moorsel JM, Kneepkens CMF. Lactitol, lactulose, and blood ammonia. Lancet 1987; ii: 688 .

16 Herrmann R, Weber FL Jr. Lactulose and ammonia. Lance 1987; ii: 1333 .

17 Weber FL, Veach G. The importance of the small intestine in gut ammonia production in the fasting dog. Gastroenterology 1979; $77: 235-40$.

18 Van Leeuwen PAM, Bogaart EJM, Janssen MA, de Boer JEG, van Eyk HMA, Soeters PB. Ammonia production and glutamine metabolism in the small and large intestine of the 
rat and the influence of lactulose and neomycin. In: Kleinkerger G, Ferenci P, Riederer P, Thaler H, eds. Basel Karger, 1984: 154-63.

19 Van Leeuwen PAM, Soeters PB. Glutamine metabolism in villus and crypt enterocytes of conventional and germ-free rats [Abstract]. Hepatology 1986; 6: 1133 .

20 Van Leeuwen PAM, Drukker J, van Kleyn NM, van den Bogaart AEJM, Soeters PB. Morphological effects of high dose neomycin sulfate on the small and large intestine. Acta Morphol Neerl Scand 1986; 24: 223-34.

21 Van Leeuwen PAM, Van Berlo CLH, Soeters PB. New mode of action for lactulose. Lancet 1988; i: 55.

22 Elkington SG, Floch MH, Conn HO. Lactulose in the reatment of chronic portal-systemic encephalopathy: double blind clinical trial. $N$ Englf Med 1969; 281: 408-12. 23 Conn HO, Leavy CM, Vlahcevic ZR, et al. Comparison of lactulose and neomycin in the treatment of chronic portalsystemic encephalopathy. Gastroenterology 1977; 72: 573-83. 24 Brown CL, Hill MJ. Bacterial ureases in uremic men. Lance 1971; ii: 406-7.

25 Morgan MH, Read AE, Speller CE. Treatment of hepatic encephalopathy with metronidazole. Gut 1982; 23: 1-7. 